\title{
Taenia solium taeniosis/cysticercosis and the co-distribution with schistosomiasis in Africa
}

\author{
Uffe Christian Braae ${ }^{1 *}$, Christopher F. L. Saarnak', Samson Mukaratirwa², Brecht Devleesschauwer ${ }^{3,4}$, \\ Pascal Magnussen ${ }^{1,5}$ and Maria Vang Johansen'
}

\begin{abstract}
Background: This study aimed to map the distribution of Taenia solium taeniosis/cysticercosis and the co-distribution with schistosomiasis in Africa. These two major neglected tropical diseases are presumed to be widely distributed in Africa, but currently the level of co-distribution is unclear.

Methods: A literature search on T. solium taeniosis/cysticercosis was performed to compile all known studies on the presence of T. solium and apparent prevalence of taeniosis and porcine cysticercosis in Africa. Studies were geo-referenced using an online gazetteer. A Bayesian framework was used to combine the epidemiological data on the apparent prevalence with external information on test characteristics to estimate informed district-level prevalence of taeniosis and porcine cysticercosis. Districts with $T$. solium taeniosis/cysticercosis presence were cross-referenced with the Global Neglected Tropical Diseases Database for schistosomiasis presence.

Results: The search strategies identified 141 reports of T. solium in Africa from 1985 to 2014 from a total of 476 districts in 29 countries, 20 with porcine cysticercosis, 22 with human cysticercosis, and 16 with taeniosis, in addition to 2 countries identified from OIE reports. All 31 countries were considered, on national scale, to have co-distribution with schistosomiasis. Presence of both parasites was confirmed in 124 districts in 17 countries. The informed prevalence of taeniosis and porcine cysticercosis were estimated for 14 and 41 districts in 10 and 13 countries, respectively.

Conclusions: With the paucity of data, T. solium infection is grossly under-reported and expected to be more widespread than this study suggests. In areas where co-distribution occurs there is a need for increased emphasis on evaluation of integrated intervention approaches for these two helminth infections and allocation of resources for evaluating the extent of adverse effects caused by mass drug administration.
\end{abstract}

Keywords: African pig population, Co-distribution, Cysticercosis, Mapping, Prevalence, Schistosomiasis, Taenia solium

\section{Background}

The major neglected tropical diseases, Taenia solium taeniosis/cysticercosis and schistosomiasis caused by Schistosoma mansoni or S. haematobium are presumed to be widely distributed in Africa. Taenia solium taeniosis/ cysticercosis has been reported as an emerging disease in different regions of Africa [1,2], but currently the exact distribution remains unclear. Reported prevalences of T. solium taeniosis and cysticercosis in African countries are not extensive and are further complicated by the lack of 'gold standard' tests for diagnosis. Diagnosis has so far

\footnotetext{
* Correspondence: braae@sund.ku.dk

'Department of Veterinary Disease Biology, Section for Parasitology and Aquatic Diseases, Faculty of Health and Medical Sciences, University of Copenhagen, DK-1870 Frederiksberg, Denmark

Full list of author information is available at the end of the article
}

been performed using several diagnostic tests with varying sensitivity and specificity [3-5]. Therefore, estimating informed prevalence is important to determine the actual disease burden. Informed prevalence is an estimation of the true prevalence based on the apparent prevalence while factoring in the imperfections in sensitivity and specificity of the diagnostic tests used. The distribution of schistosomiasis in Africa has been more extensively investigated than T. solium taeniosis/cysticercosis and this has allowed for country level prevalence and risk estimation of schistosomiasis for all African countries [6].

The World Health Organization (WHO) is aiming for elimination of schistosomiasis by 2020 and the road map for elimination of $T$. solium taeniosis/cysticercosis is under consideration by the WHO [7]. The WHO strategy for 
schistosomiasis elimination is primarily mass drug administration (MDA) of preventive chemotherapy as the main intervention tool. The $\mathrm{WHO}$ advocates that MDA against schistosomiasis will reduce morbidity and decrease transmission, which might also carry the added benefit of controlling other infections in co-endemic areas such as T. solium taeniosis/cysticercosis [7]. A way forward for control of T. solium is integration with schistosomiasis control programmes. However, the potential benefit of an integrated control effort against the two parasites has yet to be evaluated. The anthelminthic drug used against schistosomiasis is praziquantel (PZQ) because of its safety profile, easy administration, and mild side-effects [7]. The current recommended dose of PZQ for treatment of schistosomiasis is $40 \mathrm{mg} / \mathrm{kg}$ as a single dose [8]. PZQ has proved highly efficacious against taeniosis at a dose of 5$10 \mathrm{mg} / \mathrm{kg}$ [9], and the drug can therefore be used against both parasites. However, the dose recommended for schistosomiasis treatment may increase the risk of seizures in people who are suffering from human cysticercosis where the larvae are lodged in the central nervous system (neurocysticercosis, NCC). Even a single dose, lower than that recommended for schistosomiasis treatment, has been reported to induce seizures [10]. Flisser and colleagues [11] reported suspected cases of NCC based on clinical signs following treatment with $5 \mathrm{mg} / \mathrm{kg} \mathrm{PZQ}$, and in a followup of 2452 participants subjected to an MDA using PZQ at $5 \mathrm{mg} / \mathrm{kg}$ where of $1.3 \%$ reported complaints of severe headache after treatment. Although MDA has been widely applied for control of schistosomiasis in Africa, the safety of PZQ in MDA in communities where schistosomiasis and NCC coexist is yet to be systematically assessed.

The distribution of T. solium taeniosis/cysticercosis in Africa is unclear and up-to-date prevalence maps do not exist. The distribution of schistosomiasis is also to some extent uncertain, but through the work of the Global Neglected Tropical Diseases Database (GNTD; http:// www.gntd.org), a prevalence map based on more than 20,000 locations can be created. The database is continuously updated with the goal to use the information for public health campaigns against schistosomiasis. With the launch of online virtual globes such as Google Earth, online gazetteers have become a useful tool for geo-referencing of locations and also disease distribution. The GNTD has used online gazetteers in order to geographically locate the distribution of schistosomiasis [12], which in turn have been utilised for modelling past and future distribution maps of infection [13-15]. This paper aims to compile the available information on T. solium taeniosis/cysticercosis in Africa and use the information to estimate the informed prevalence of taeniosis and porcine cysticercosis on a district level, and determine districts were co-distribution of T. solium taeniosis/cysticercosis and schistosomiasis occurs.

\section{Methods}

\section{Literature search}

The following data were included in this study 1) peerreviewed studies of $T$. solium taeniosis/cysticercosis in Africa, 2) "grey literature" on T. solium taeniosis/cysticercosis presence in Africa which consisted of informally published written materials such as reports and theses, 3) official reports of national pig populations in Africa available through national census data and FAOSTAT [16], the statistical database of the Food and Agriculture Organization of the United Nations, 4) porcine cysticercosis reports from the World Organisation for Animal Health (OIE), and 5) the schistosomiasis prevalence map currently used by the WHO for assessing MDA intervals [17].

We performed a literature search using PubMed (http:// www.ncbi.nlm.nih.gov/pubmed/) with date restriction from 01-01-1985 to 05-01-2015 using the following search term: (solium OR Tapeworm OR Taeniasis OR Taeni* OR Taeniosis OR Neurocysticercosis OR Cysticerc* OR cellulosae) AND (Algeria OR Angola OR Benin OR Botswana OR Burkina Faso OR Burundi OR Cameroon OR Central African Republic OR Chad OR Congo OR Zaire OR Cote d'Ivoire OR Ivory Coast OR Djibouti OR Egypt OR Equatorial Guinea OR Eritrea OR Ethiopia OR Gabon OR Gambia OR Ghana OR Guinea OR Guinea-Bissau OR Kenya OR Lesotho OR Liberia OR Libya OR Madagascar OR Malawi OR Mali OR Mauritania OR Morocco OR Mozambique OR Namibia OR Niger OR Nigeria OR Rwanda OR Senegal OR Sierra Leone OR Somalia OR South Africa OR South Sudan OR Sudan OR Swaziland OR Tanzania OR Togo OR Tunisia OR Uganda OR Zambia OR Zimbabwe). We also searched other databases such as Google Scholar (http://scholar. google.com), Thomson Reuter's Web of Knowledge (http://www.wokinfo.com), Cab Direct (http://www.cab direct.org), Société de Pathologie Exotique (http://www. pathexo.fr/), ProMED (http://www.isid.org), and African Journals Online (http://www.ajolinfo) using the following keywords: "Taenia solium", "porcine cysticercosis", "Cysticercus cellulosae", "neurocysticercosis", "human cysticercosis", "taeniosis", and "taeniasis". In addition, references found in suitable articles were also investigated to compile all known studies on presence of T. solium and prevalence of taeniosis and porcine cysticercosis.

\section{Data extraction}

Presence of T. solium in this study was defined as a documented case of disease related to the T. solium tapeworm, whether it was diagnosed and documented as porcine cysticercosis, taeniosis, or human cysticercosis. Initially we reviewed all titles and abstracts, if accessible, and excluded studies from outside Africa, studies based on questionnaire only, environmental studies, and studies with no reference to geographical location. Authors 
of articles where full-text were inaccessible were contacted. The remaining studies were excluded if full-text was not available or if based on experimental studies where location of infection could not be established (Fig. 1). Studies on human cysticercosis were only included if the authors provided approximate location of where the patient presumably caught the infection. For example, Pönnighaus and colleagues [18] reported a case of cutaneous cysticercosis in Malawi, where it was beyond doubt that the disease had been acquired within the country. Other reports such as NCC cases suspected to be autochthonous but not confirmed were omitted. In order to reduce the risk of including $T$. saginata infections, studies reporting taeniosis, but without confirmation of the $T$. solium tapeworm, were only included if reports of porcine cysticercosis could be found for the respective country or if the OIE reported porcine cysticercosis to be present in the respective country.

Taenia solium taeniosis/cysticercosis cases were georeferenced by extracting geographic information on the study quoted in the literature. If no geographic coordinates were provided by the authors, the geographic location was found by using the online gazetteer 'Geonames' (http://geonames.org). Distribution of schistosomiasis was extracted as point data from the GNTD and overlaid on the district-level occurrence of T. solium taeniosis/cysticercosis to determine districts with co-distribution.

Informed district-level prevalence of taeniosis and porcine cysticercosis was estimated from apparent prevalence estimates extracted from the literature and external information on the sensitivity and specificity of the applied diagnostic tests. Data was only extracted if applied diagnostic tests, denominators and the number of positive subjects were provided. If multiple studies existed from the same second-level administrative division, the mapping was based on survey year (most recent), and then highest informed prevalence (Fig. 2). For studies were informed prevalence could be estimated based on multiple test assessment [19], this more informed estimate was preferred over the corresponding single test estimates. Studies with sample sizes of less than 30 individuals were excluded. Bayesian inference was used to obtain the informed prevalence estimates [20], using the functions in the $\mathrm{R}$ package prevalence version 0.3.0 [21]. The parameters for the probabilistic constraints in terms of sensitivity and specificity of the diagnostic tests used were obtained from key papers using the $95 \%$ confidence intervals reported (Table 1 ). Further information and source code for both the single and multiple test informed prevalence assessments

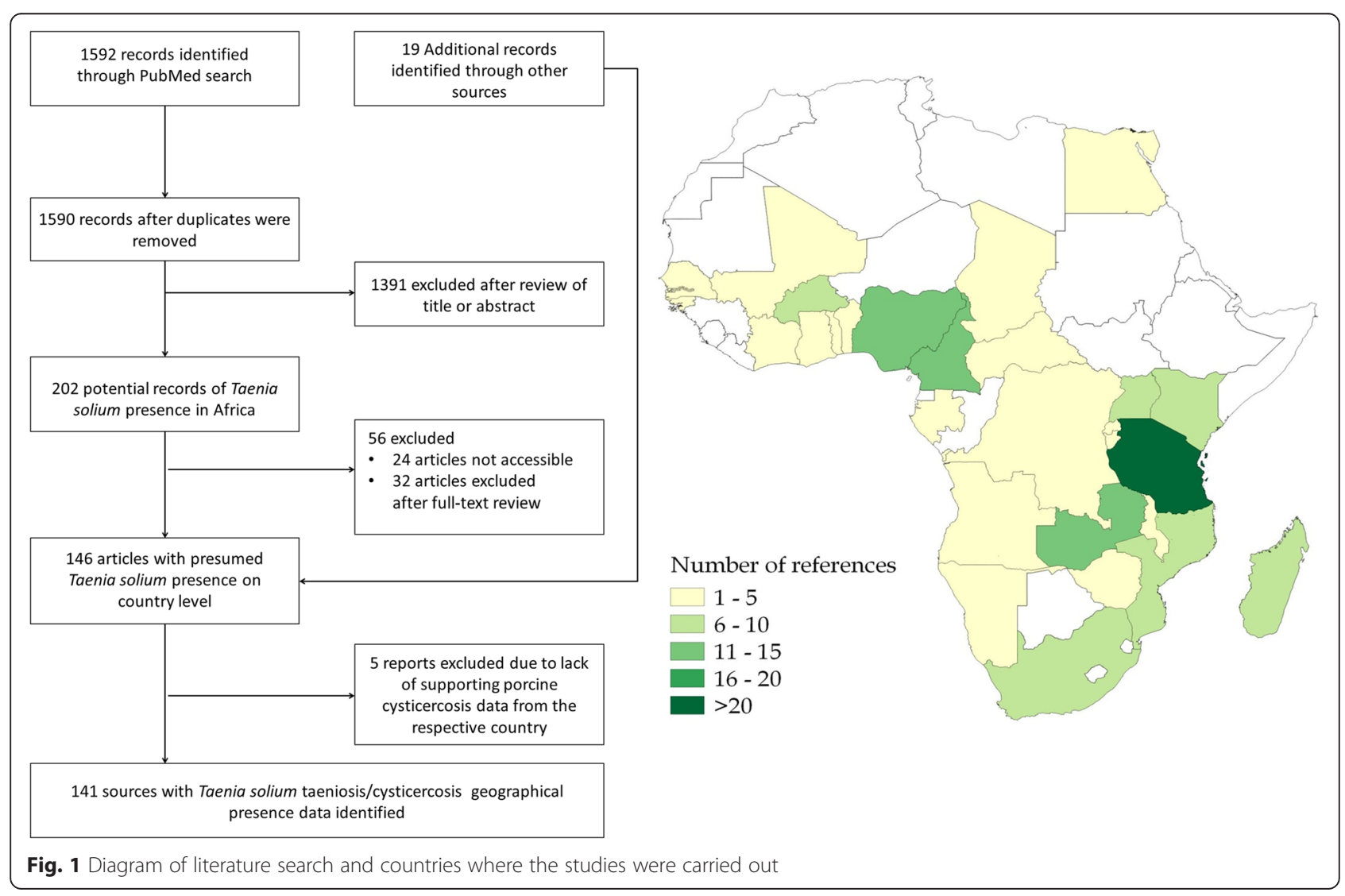




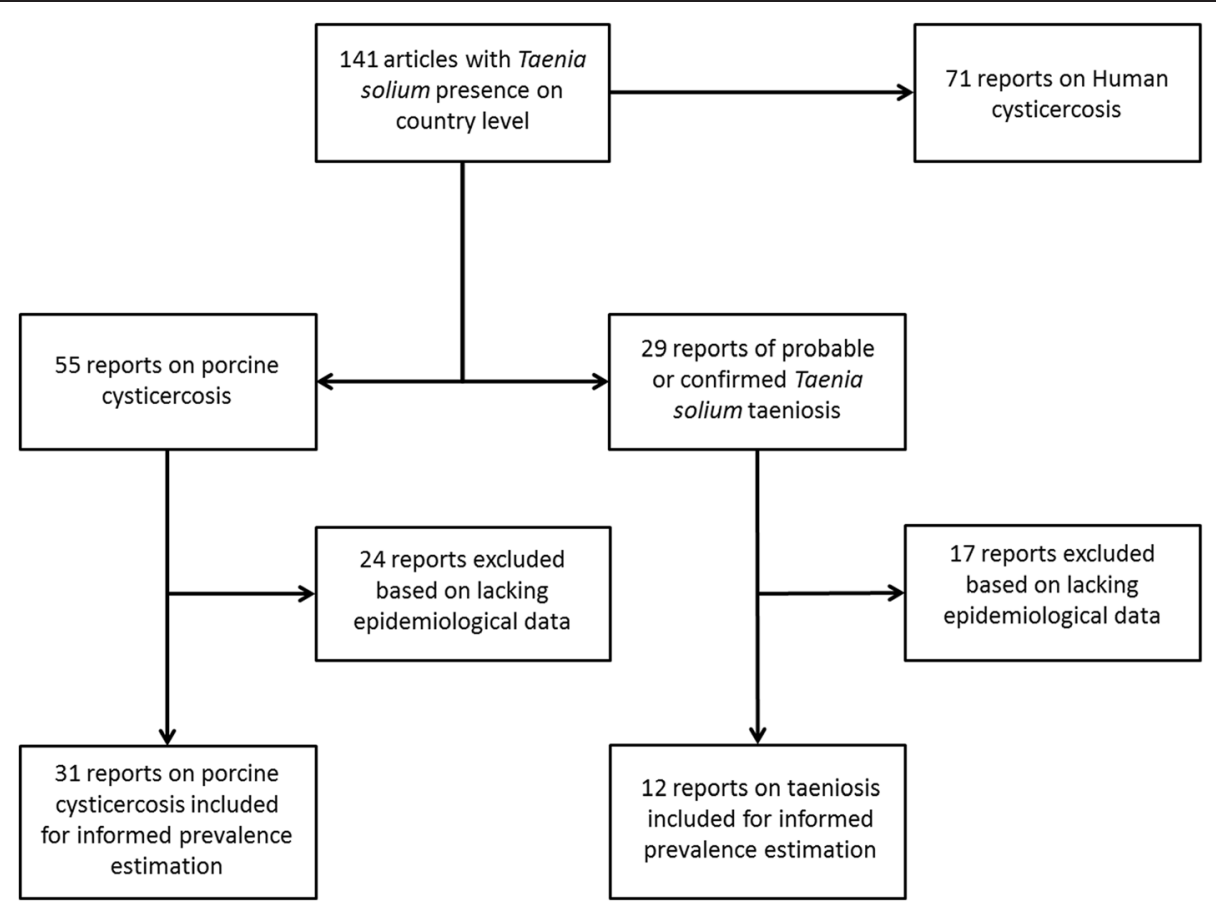

Fig. 2 Flow chart of the selection of literature for the informed prevalence estimations

are available in the Additional file 1: Informed prevalence estimation.

Data on the African pig population were extracted from national livestock census reports or FAOSTAT database if national census data were missing, and divided with the countries human population obtained from the UN to yield a per capita pig population [22]. Data on recent (2005 to 2014) reports of porcine cysticercosis that have been submitted to the OIE were extracted from the OIE database WAHID Interface [23]. Reports from the database are in 6 months intervals with disease status divided into 5 categories: disease was present, suspected but not confirmed, not reported during this period, never reported, and no information available. We have pooled the data into one 'disease status' during the period 2005 to 2014, ranking the five categories in the following order 1) disease was present, 2) suspected but not confirmed, 3) not reported during this period, 4) never reported, and 5) no information available.

\section{Results}

The search strategies identified 141 reports of T. solium taeniosis/cysticercosis in Africa from 1985 to 2014, written in English, French, Portuguese, Italian, Danish, and German. The reports confirmed presence of $T$. solium taeniosis/cysticercosis in 476 second-level administrative units (i.e., districts) or equivalent from 29 African countries, with porcine cysticercosis reported in 20 countries, human cysticercosis reported in 22 countries, and taeniosis reported in 16 countries of which only 3 countries had studies confirming T. solium taeniosis cases (Table 2). No attempts were made to differentiate between T. solium and T. saginata infections in the reports from the remaining 13 countries. For additional 2 countries (Côte d'Ivoire [24]

Table 1 Parameters used for the probabilistic constraints for sensitivity and specificity of the different diagnostic tests using the $95 \%$ confidence intervals reported in key papers

\begin{tabular}{lllll}
\hline Test & Disease & Sensitivity (\%) & Specificity (\%) & Reference \\
\hline Lingual examination & Porcine cysticercosis & $16.1-21.0$ & $90.0-100$ & {$[4]$} \\
Post-mortem & Porcine cysticercosis & $22.1-38.7$ & $90.0-100$ & {$[4]$} \\
Ag-ELISA (B158/B60) & Porcine cysticercosis & $64.5-86.7$ & $91.2-94.7$ & {$[4]$} \\
Ag-ELISA (HP10) & Porcine cysticercosis & $52.7-84.7$ & $44.6-85.1$ & \\
Coprology & Taeniosis & $11.1-96.5$ & $99.5-100^{\text {a }}$ & {$[54,55]$} \\
Copro-Ag-ELISA & Taeniosis & $61.9-98.0$ & $90.0-93.8$ & {$[56]$} \\
\hline
\end{tabular}

${ }^{\mathrm{a} T e s t}$ only genus specific 
Table 2 Presence of Taenia solium cysticercosis recorded in African countries from 1985 to 2014. Taenia solium taeniosis was not confirmed unless otherwise stated

\begin{tabular}{|c|c|c|c|c|}
\hline Country & Porcine cysticercosis & Taeniosis & Human cysticercosis & No of References \\
\hline Angola & & {$[57]$} & & 1 \\
\hline Benin & {$[58]$} & & [59-61] & 4 \\
\hline Burkina Faso & {$[62]$} & & {$[63-69]$} & 8 \\
\hline Burundi & [70] & {$[70]$} & {$[41,70-73]$} & 5 \\
\hline Cameroon & {$[74-78]$} & {$[79,80]^{a}$} & {$[79,81-87]$} & 7 \\
\hline Central African Republic & & & [88] & 1 \\
\hline Chad & {$[78]$} & & & 1 \\
\hline Côte d'Ivoire & & {$[24]$} & & 1 \\
\hline Democratic Republic of Congo & {$[89,90]$} & {$[38]$} & [38] & 3 \\
\hline Egypt & [91] & & & 1 \\
\hline Gabon & & & {$[92]$} & 1 \\
\hline Gambia & [93] & & & 1 \\
\hline Ghana & [94] & & {$[95]$} & 2 \\
\hline Guinea-Bissau & & {$[96,97]$} & & 2 \\
\hline Kenya & {$[30,98-100]$} & & {$[95,101]$} & 6 \\
\hline Madagascar & [102-104] & {$[105]$} & [106-111] & 10 \\
\hline Malawi & & & {$[18,112]$} & 2 \\
\hline Mali & & & [113] & 1 \\
\hline Mozambique & {$[51,114,115]$} & {$[116]^{a}$} & [116-118] & 6 \\
\hline Namibia & & {$[25]$} & & 1 \\
\hline Nigeria & [119-123] & {$[120,123-127]$} & {$[40,128,129]$} & 12 \\
\hline Rwanda & & & [130] & 1 \\
\hline Senegal & [93] & {$[131,132]$} & [132] & 3 \\
\hline South Africa & {$[55]$} & {$[133,134]$} & {$[95,133,135-140]$} & 10 \\
\hline Tanzania & {$[28,29,31,141-150]$} & {$[39,151]^{\mathrm{a}}$} & {$[39,95,152-156]$} & 21 \\
\hline Togo & [157] & {$[157]$} & [158-161] & 5 \\
\hline Uganda & [162-167] & {$[168]$} & {$[95,169]$} & 9 \\
\hline Zambia & {$[4,52,170-172]$} & {$[36,173-175]$} & {$[36,42,173,174,176,177]$} & 12 \\
\hline Zimbabwe & {$[178]$} & & {$[179,180]$} & 3 \\
\hline
\end{tabular}

${ }^{a}$ Confirmed Taenia solium taeniosis cases

and Namibia [25]) totalling 31 countries, data were included based on OIE reports of porcine cysticercosis. This was for Côte d'Ivoire further supported by older literature documenting T. solium presence [26], but since neither studies on porcine cysticercosis nor human cysticercosis could be found in the literature search for Namibia, the presence of T. solium based on taeniosis is therefore uncertain. In Lesotho and Swaziland, no official information was found but T. solium presence in Lesotho has been mentioned in literature [27]. However, this was not deemed sufficient to be included in this study. There is a paucity of data from North Africa, but presumably due to the cultural/religious beliefs prevailing in the region, low prevalence could be expected. However, since pigs are kept in the region, we cannot assume the region is disease free.
According to the ranking of OIE's reports of porcine cysticercosis for 2005-2014, the disease was present in 18 African countries and additionally suspected in three: Equatorial Guinea, Kenya, and Tanzania. For both Kenya and Tanzania, literature confirms the presence of T. solium during this period [28-31], but no data exist from Equatorial Guinea. This indicates insufficient national reporting to the OIE. In 2 of the 18 countries with porcine cysticercosis according to the OIE, i.e., Congo and Niger, no other documentation of $T$. solium presence could be found.

Figure 3 shows the presence of T. solium taeniosis/cysticercosis on national and district levels on the African continent and Madagascar. Data are not readily available for many African countries and in countries where data 


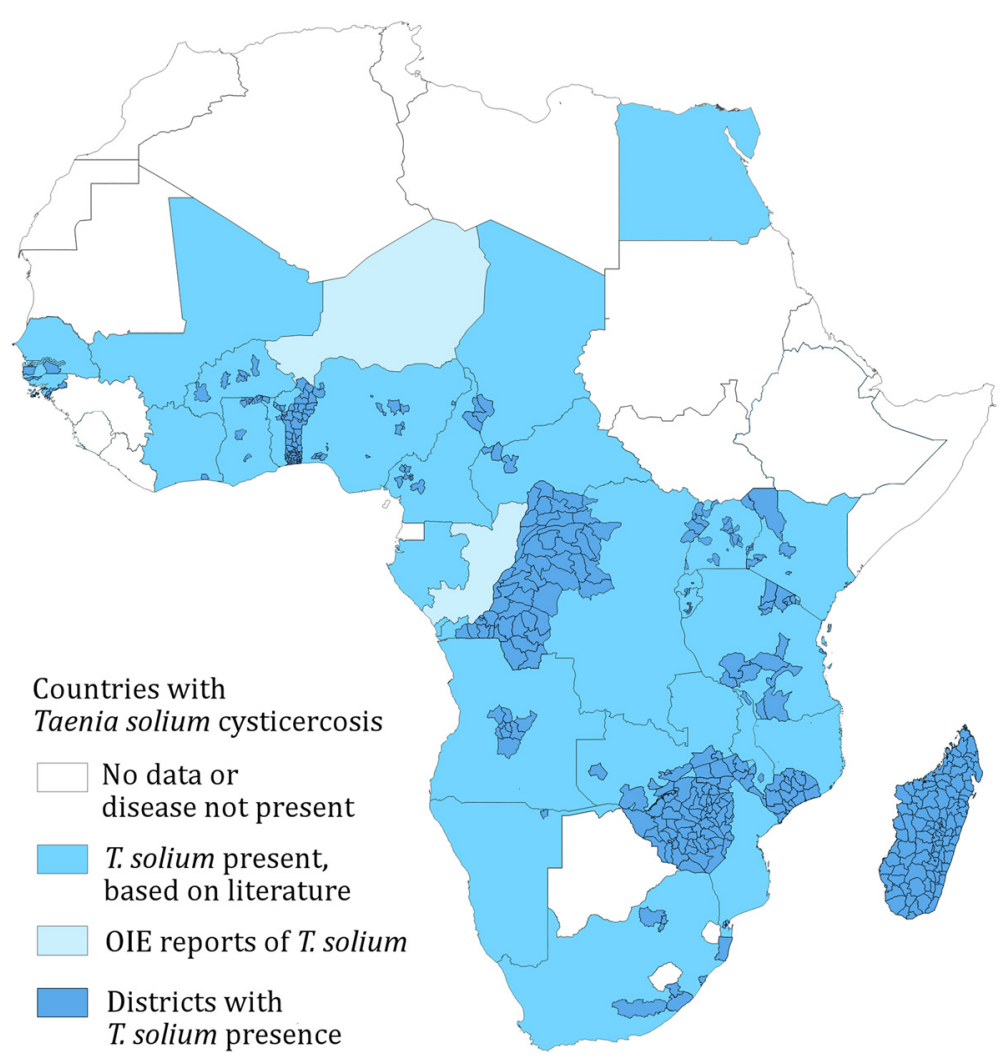

Fig. 3 African countries and districts where Taenia solium taeniosis/cysticercosis has been confirmed from 1985 to 2014

exist there are large areas in which prevalence is unknown. Importantly there are 10 African countries where pig keeping is known to take place, but in which no data exists for the presence of T. solium. Although, in three of these countries the pig population per capita is relatively low (Fig. 4).

Figure 5 shows the presence of T. solium taeniosis/ cysticercosis in Africa super-imposed onto African countries where the WHO recommended MDA against schistosomiasis with three different treatment intervals based on prevalence; high ( $\geq 50 \%)$, medium $(\geq 10$ to $<50 \%)$, and low $(<10 \%)$. High prevalence areas fall under the recommendation of annual MDA of PZQ to all school-aged children and populations at risk. In medium prevalence areas biennially MDA of PZQ to all school-aged children are recommended, and in low prevalence areas all schoolaged children should be treated twice during their schooling. In all 31 countries where T. solium taeniosis/ cysticercosis was found, MDA was also recommended for control of schistosomiasis. Taenia solium has been confirmed in four countries (Ghana, Madagascar, Mozambique, and Tanzania) out of the five schistosomiasis high prevalence countries. No information is available for the fifth country (Sierra Leone) in terms of T. solium distribution, but pigs are present (Fig. 4). The WHO MDA recommendations represent an estimate of the mean schistosomiasis burden within a country. By overlaying the GNTD data on schistosomiasis with the district data on T. solium distribution, we found co-distribution in 124 out of the 476 districts were $T$. solium occurred. In these districts the GNTD data showed a mean schistosomiasis prevalence of $23.1 \%$, with a mean maximum prevalence of $49.6 \%$.

Figures 6 and 7 represent the informed prevalence estimated for T. solium taeniosis and porcine cysticercosis, respectively, based on the studies that fulfilled the criteria for Bayesian inference (Table 3), and the selection criteria. Informed prevalence for taeniosis was calculated for 14 districts in 10 countries out of the 16 countries in which taeniosis were found (Fig. 6). For Côte d'Ivoire, Madagascar, Mozambique, Namibia, Togo, and Zimbabwe the literature did not contain the necessary epidemiological information and was excluded from the analysis. Informed prevalence for porcine cysticercosis was estimated for 41 districts in 13 out of the 20 countries in which porcine cysticercosis were confirmed (Fig. 7). Finally, detailed epidemiological data on porcine cysticercosis infection were missing from 7 (65\%) out of the 20 endemic countries based on the literature.

\section{Discussion}

Taenia solium taeniosis/cysticercosis was confirmed in 476 districts in 29 African countries based on the 




Fig. 4 African pig population per capita on a national level in 2011. National pig populations were obtained from census reports or FAOSTAT

literature search. According to the OIE reports from 2005 to 2014, the parasite is present in additional two countries, totalling 31 endemic countries in Africa. The findings correspond well to the WHO risk map for cysticercosis previously published [32], but have a much higher level of accuracy with distribution on district level in certain areas. With only 141 references identified from surveys in Africa, occurrence is probably grossly underreported. Several countries e.g. Guinea, Sierra Leone, and Liberia, with relatively large porcine populations still need to be investigated for T. solium presence, which emphasises the need for more research on disease distribution. However, this is complicated by the fact that T. solium has a focal distribution [33]. Pig keeping is far from evenly distributed across the African continent, nor within single countries, region or even districts.

In all 31 countries where $T$. solium occurrence was documented, schistosomiasis and T. solium taeniosis/ cysticercosis can be considered to co-exist. Data on the distribution of $T$. solium is sparse on the district level and more data is essential to construct more accurate co-distribution maps, but nonetheless co-distribution was confirmed in 124 districts in 17 countries. Identifying co-endemic clusters on the same administrative level as MDA is carried out in the respective countries will enable identification of communities at risk of adverse effects from treatment with PZQ due to NCC. Even at village level significant variation in disease distribution is expected for both schistosomiasis and T. solium taeniosis/cysticercosis, as transmission of the disease is dependent on the presences of the respective intermediate hosts. This can result in large differences in disease prevalence within small geographical areas. However, since inadequate sanitation is an important risk factor for both parasites, frequent overlaps would be expected.

According to the WHO, preventive chemotherapy against schistosomiasis is required in some districts of all sub-Saharan countries, except Lesotho where the disease is not endemic [17]. More than 240 million people in Africa were in need of preventive chemotherapy against schistosomiasis in 2013 and just over 130 million of these were school-aged children [34]. School-aged children typically make-up a relatively large proportion of the total population within African countries and are considered the main group at risk for severe schistosomiasis morbidity and main contributors to egg excretion [35]. Taeniosis is however more equally distributed across age groups within the population [36], thus MDA of PZQ to school-aged children might therefore not be sufficient to significantly lower Taenia egg excretion within a community even though school-aged children make-up a large proportion of the population [37]. 


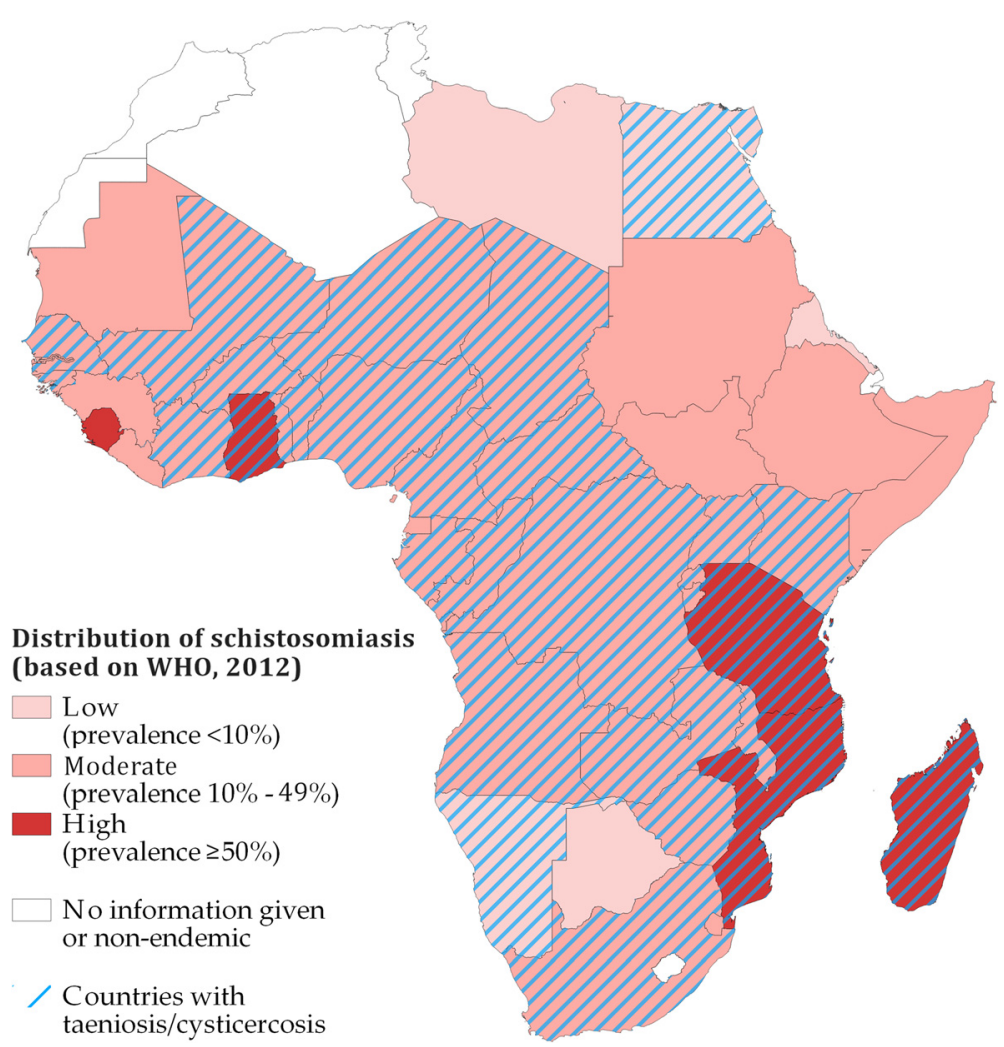

Fig. 5 Co-distribution of Taenia solium infections in humans and/or pigs and schistosomiasis in Africa based on studies from 1985 to 2014

Currently there has been no monitoring or evaluation of MDA for schistosomiasis in communities where $T$. solium taeniosis/cysticercosis and schistosomiasis are co-distributed, which is highly warranted. Since the geographical distribution of $T$. solium remains to be fully elucidated in most African countries, the risk of adverse effects could be significantly underestimated. Several studies in Africa have confirmed the presence of human cysticercosis and specifically NCC in areas where schistosomiasis is endemic [36, 38-41]. Although NCC is considered more common in adults [42], children are also infected and in South Africa children down to the age of three have been found to suffer from NCC [43].

On-going control programmes in communities where pigs are kept or consumed, should be systematically monitored for adverse events that may incur from NCC in order to make precautionary implementations for future MDAs, such as determining prevalence of NCC in communities. Therefore, the number of pigs present in the communities, regions, and countries is an important key figure to obtain. Currently few African countries have performed a national census on livestock which makes the presumed rough estimates on national pig populations in Africa from FAOSTAT the only data available. However, the problem of NCC is not necessarily confined to areas where pigs are kept. Numerous accounts have shown that persons who neither raise pigs nor consume pork are also at risk of cysticercosis as people can accidently ingest $T$. solium eggs after coming into direct or indirect contact with tapeworm carriers, irrespective of their own cultural and religious practices or the presence of pigs [44-47]. Therefore, communication between the veterinary and public health sector is crucial for local authorities to get insight into the consequences of applying MDA to communities where schistosomiasis and T. solium taeniosis/cysticercosis are co-endemic.

Findings from the literature search indicate a discrepancy between the reports on the presence of porcine cysticercosis stated in the literature and that of which has been reported to the OIE. This may be due to porcine cysticercosis not being an international notifiable disease, which may lead to inconsistencies in reporting to the OIE by member states. There is a need to improve communication between the scientific community and OIE in addition to the respective member states from Africa to alleviate this problem.

The informed prevalences of taeniosis and porcine cysticercosis should be regarded as best estimates rather than absolute truths. Sensitivity and specificity are not necessarily intrinsic to the specific diagnostic test used, but affected by external factors [48], or by the intensity 


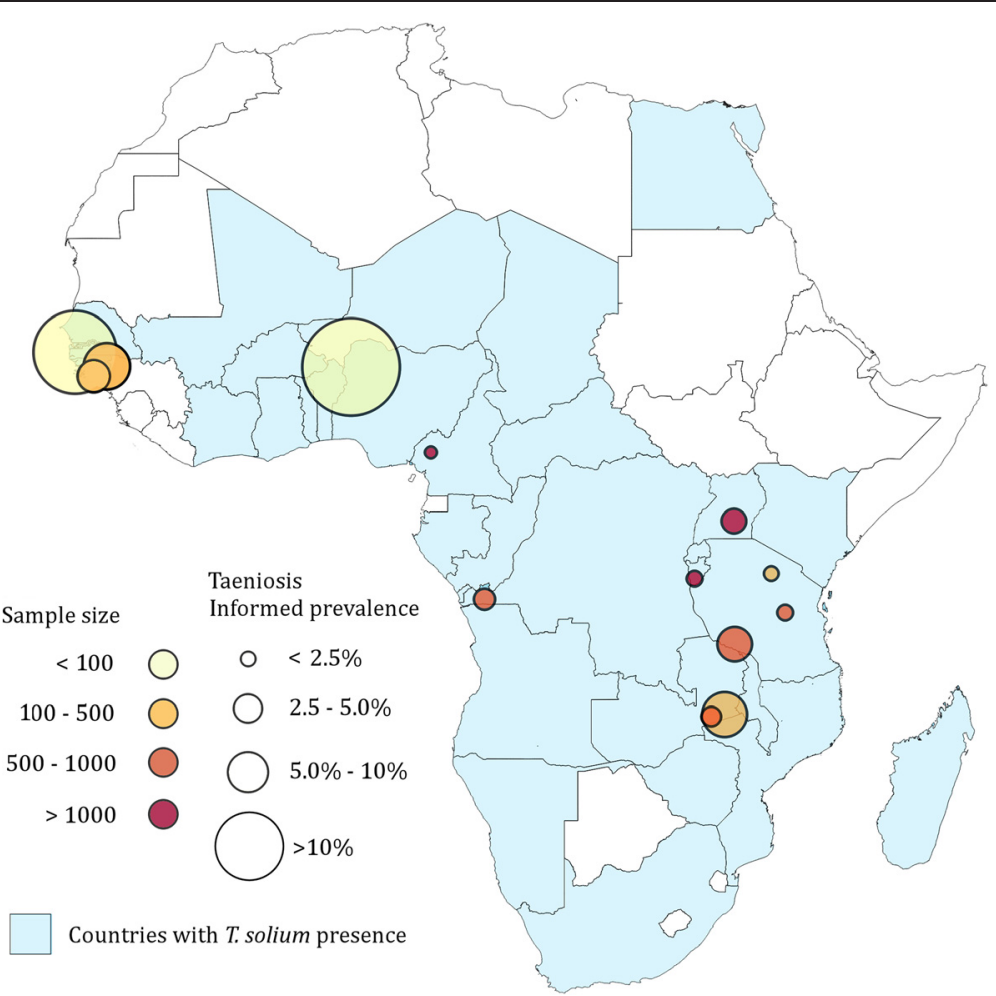

Fig. 6 Informed prevalence of taeniosis in Africa from 1983 to 2010

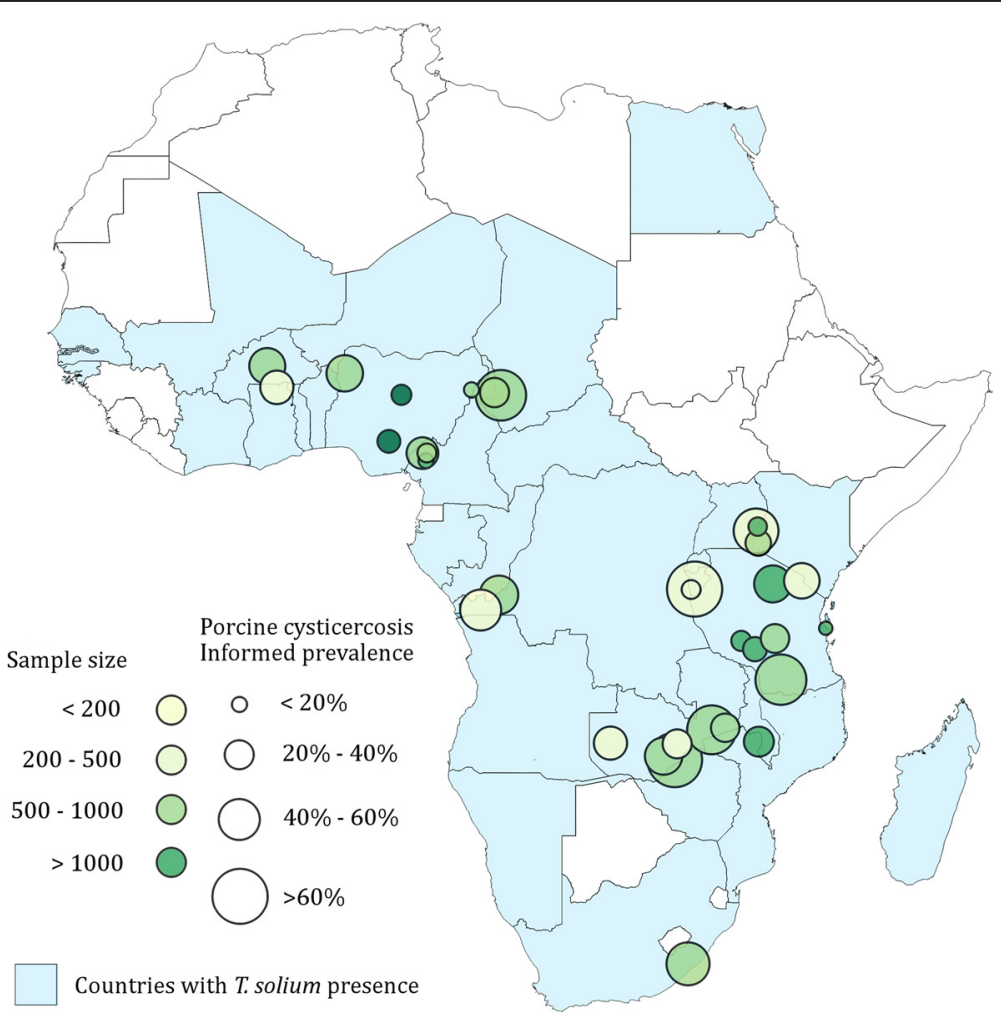

Fig. 7 Informed prevalence of porcine cysticercosis in Africa from 1985 to 2013 
Table 3 Studies included in the calculation of informed prevalence of Taenia solium taeniosis and porcine cysticercosis by Bayesian inference

\begin{tabular}{lll}
\hline Country & Porcine cysticercosis & Taeniosis \\
\hline Burkina Faso & {$[62]$} & \\
Burundi & {$[70]$} & {$[70]$} \\
Cameroon & {$[74-78]$} & {$[80]^{\mathrm{a}}$} \\
Chad & {$[78]$} & \\
Democratic Republic of Congo & {$[90]$} & {$[38]$} \\
Ghana & {$[94]$} & \\
Guinea-Bissau & & {$[96,97]$} \\
Kenya & {$[30,98-100]$} & \\
Mozambique & {$[51]$} & \\
Nigeria & {$[119-121,123]$} & {$[120]$} \\
Senegal & & {$[132]$} \\
South Africa & {$[54]$} & {$[133]$} \\
Tanzania & {$[29,31,141,142$,} & {$[39,151]^{\mathrm{a}}$} \\
& $144,149,150]$ & \\
Uganda & {$[167]$} & {$[168]$} \\
Zambia & {$[4,170-172]$} & {$[36]$} \\
\hline
\end{tabular}

${ }^{a}$ Cases of Taenia solium taeniosis confirmed

of the infection, which commonly vary among studies [49]. The Bayesian inference does however give the best possible comparison and thereby provides a rough overview of the disease burden within certain areas in the affected countries. Unfortunately, it does not provide any information on the $T$. solium cysticercosis burden for any entire nation. This requires more detailed nationwide epidemiological surveys [50].

Allowing pigs to roam freely is a well-known risk factor for porcine cysticercosis [51, 52], but production type and management were not considered in the study. Likewise, no differentiation was made between studies performed at slaughter slabs and farms. There is consensus that pigs in endemic African countries often are screened for cysticercosis by tongue examination before being sent for slaughter, resulting in higher apparent prevalence on farms compared to slaughter slabs. This causes bias in the surveys performed at slaughter slabs, which will underestimate the prevalence of porcine cysticercosis, because pigs with high intensity infections have been eliminated from the sample.

Pinpointing the origin of $T$. solium cases is difficult because taeniosis is often asymptomatic and symptoms of NCC often occur between 2 and 5 years after infection [53]. Thus, the subject would therefore require accurate long-term recollection of where and when the infection might have been contracted, and depending on travel history of the infected person the infection might not have been acquired at the same place as they were surveyed.

\section{Conclusion}

Although T. solium is reported from the majority of African countries it is still grossly under-reported and for many areas the co-distribution with schistosomiasis on district level is still unknown. In areas where T. solium and schistosomiasis is co-distributed, an increased emphasis should be put on evaluating an integrated intervention approach for these two helminth infections. Resources should be allocated to evaluate the extent of adverse effects caused by the MDA of PZQ as preventive treatment in areas where people suffer from NCC. On-going control programmes should therefore be monitored, but reaching the goal of eliminating $T$. solium will require a One Health approach addressing both human and animal health.

\section{Additional file}

Additional file 1: Informed prevalence estimation. Estimating

informed prevalence of Taenia solium taeniosis/cysticercosis in Africa.

\section{Competing interests}

The authors declare that they have no competing interests.

\section{Authors' contributions}

All authors participated in the design of the study. UCB and CS carried out the data collection and UCB and BD performed the statistical analysis. CS made all maps. UCB drafted the manuscript, with subsequent input from all other authors. All authors read and approved the final manuscript.

\section{Acknowledgements}

Dr Davies Pfukenyi from the Faculty of Veterinary Science, University of Zimbabwe for supplying us with $T$. solium data from Zimbabwe.

\section{Role of funding source}

The funder had no role in study design, data collection, analysis, interpretation of the data, or drafting of the manuscript. The corresponding author had full access to all data in the study and had the final responsibility for decision to submit for publication.

\section{Author details}

${ }^{1}$ Department of Veterinary Disease Biology, Section for Parasitology and Aquatic Diseases, Faculty of Health and Medical Sciences, University of Copenhagen, DK-1870 Frederiksberg, Denmark. ${ }^{2}$ School of Life Sciences, University of KwaZulu-Natal, Durban, South Africa. ${ }^{3}$ Department of Virology, Parasitology and Immunology, Faculty of Veterinary Medicine, Ghent University, 9820 Merelbeke, Belgium. ${ }^{4}$ Institute of Health and Society (IRSS), Université catholique de Louvain, 1200 Brussels, Belgium. ${ }^{5}$ Centre for Medical Parasitology, Faculty of Health and Medical Sciences, University of Copenhagen, DK-1353 Copenhagen, Denmark.

Received: 6 May 2015 Accepted: 5 June 2015

Published online: 12 June 2015

\section{References}

1. Zoli A, Shey-Njila O, Assana E, Nguekam JP, Dorny P, Brandt J, et al. Regional status, epidemiology and impact of Taenia solium cysticercosis in Western and Central Africa. Acta Trop. 2003;87(1):35-42.

2. Phiri IK, Ngowi H, Afonso S, Matenga E, Boa M, Mukaratirwa S, et al. The emergence of Taenia solium cysticercosis in Eastern and Southern Africa as a serious agricultural problem and public health risk. Acta Trop. 2003;87(1):13-23.

3. Deckers N, Dorny P. Immunodiagnosis of Taenia solium taeniosis/cysticercosis. Trends Parasitol. 2010;26(3):137-44 
4. Dorny P, Phiri IK, Vercruysse J, Gabriel S, Willingham AL, Brandt J, et al. A Bayesian approach for estimating values for prevalence and diagnostic test characteristics of porcine cysticercosis. Int J Parasitol. 2004;34(5):569-76.

5. Gonzalez AE, Cama V, Gilman RH, Tsang VCW, Pilcher JB, Chavera A, et al. Prevalence and comparison of serologic assays, necropsy, and tongue examination for the diagnosis of porcine cysticercosis in Peru. Am J Trop Med Hyg. 1990;43(2):194-9.

6. Steinmann P, Keiser J, Bos R, Tanner M, Utzinger J. Schistosomiasis and water resources development: systematic review, meta-analysis, and estimates of people at risk. Lancet Infect Dis. 2006;6(7):411-25.

7. WHO. Working to overcome the global impact of neglected tropical diseases - First WHO report on neglected tropical diseases. Geneva: World Health Organization; 2010.

8. WHO. Prevention and control of schistosomiasis and soil-transmitted helminthiasis: Report of a WHO Expert Committee. World Health Organization; 2002

9. Pawlowski ZS. Efficacy of low doses of praziquantel in taeniasis. Acta Trop. 1991;48(2):83-8.

10. Torres JR. Use of praziquantel in populations at risk of neurocysticercosis. Rev Inst Med Trop Sao Paulo. 1989;31(4):290.

11. Flisser A, Madrazo I, Plancarte A, Schantz P, Allan J, Craig P, et al. Neurological symptoms in occult neurocysticercosis after single taeniacidal dose of praziquantel. Lancet. 1993;342(8873):748.

12. Hurlimann E, Schur N, Boutsika K, Stensgaard AS, de HimpsI ML, Ziegelbauer $K$, et al. Toward an open-access global database for mapping, control, and surveillance of neglected tropical diseases. Plos Negl Trop Dis. 2011;5(12):e1404

13. Stensgaard A-S, Utzinger J, Vounatsou P, Hürlimann E, Schur N, Saarnak CF, et al. Large-scale determinants of intestinal schistosomiasis and intermediate host snail distribution across Africa: does climate matter? Acta Trop. 2013;128(2):378-90.

14. Schur N, Hürlimann E, Garba A, Traoré MS, Ndir O, Ratard RC, et al. Geostatistical model-based estimates of schistosomiasis prevalence among individuals aged $\leq 20$ years in West Africa. Plos Negl Trop Dis. 2011;5(6), e1194.

15. Schur N, Hürlimann E, Stensgaard A-S, Chimfwembe K, Mushinge G, Simoonga C, et al. Spatially explicit Schistosoma infection risk in eastern Africa using Bayesian geostatistical modelling. Acta Trop. 2013;128(2):365-77.

16. FAO (Food and Agriculture Organization of the United Nations) statistical databases. [http://faostat3.fao.org/home/index.html].

17. Global Health Observatory Map Gallery. [http://gamapserver.who.int/ mapLibrary/Files/Maps/Schistosomiasis_2012.png].

18. Pönnighaus JM, Nkhosa P, Baum HP. Cutaneous manifestation of cysticercosis. Hautarzt. 2001;52(12):1098-100.

19. Berkvens D, Speybroeck N, Praet N, Adel A, Lesaffre E. Estimating disease prevalence in a Bayesian framework using probabilistic constraints. Epidemiology. 2006;17(2):145-53.

20. Speybroeck N, Devleesschauwer B, Joseph L, Berkvens D. Misclassification errors in prevalence estimation: Bayesian handling with care. Int Public Health J. 2013;58(5):791-5.

21. Devleesschauwer B, Torgerson P, Charlier J, Levecke B, Praet N, Roelandt S, et al. Prevalence: Tools for prevalence assessment studies. $R$ package version 0.3.0. 2014. Available: http://cran.r-project.org/package=prevalence.

22. World Population Prospects: The 2012 Revision. [http://esa.un.org/wpp/].

23. OIE. World Animal Health Information Database (WAHID) Interface. 2014.

24. Menan EIH, Rouamba E, Ouhon J, Nebavi NGF, Adjetey TAK, Barro-Kiki PCMK, et al. Intestinal helminthiases: results of five years of parasitological coprology at the Pasteur Institute of Cocody (Abidjan - Côte d'Ivoire). Med Afr Noire. 1997:44(7):415-9.

25. Evans AC, Joubert JJ. Intestinal helminths of hospital patients in Kavango territory, Namibia. Trans R Soc Trop Med Hyg. 1989;83(5):681-3.

26. Mishra G, N'depo A. Les cysticerques des animaux abattus à l'abattoir de Port-Bouet (Abidjan). Rev Elev Med Vet Pays Trop. 1978;31(4):431-6.

27. Motsepe T, Ackerman D. Spinal and vertebral neurocysticercosis in an HIV-positive female patient: case report. South Afr J Epidemiol Infect. 2012;27(3):133-6.

28. Mellau BL, Nonga HE, Karimuribo ED. Slaughter stock abattoir survey of carcasses and organ/offal condemnations in Arusha region, northern Tanzania. Trop Anim Health Pro. 2011;43(4):857-64.

29. Mkupasi EM, Ngowi HA, Nonga HE. Prevalence of extra-intestinal porcine helminth infections and assessment of sanitary conditions of pig slaughter slabs in Dar es Salaam city, Tanzania. Trop Anim Health Pro. 2011;43(2):417-23.
30. Eshitera EE, Githigia SM, Kitala P, Thomas LF, Fevre EM, Harrison LJS, et al. Prevalence of porcine cysticercosis and associated risk factors in Homa Bay District, Kenya. BMC Vet Res. 2012;8:234.

31. Komba EV, Kimbi EC, Ngowi HA, Kimera SI, Mlangwa JE, Lekule FP, et al. Prevalence of porcine cysticercosis and associated risk factors in smallholder pig production systems in Mbeya region, southern highlands of Tanzania. Vet Parasitol. 2013;198(3):284-91.

32. Countries and areas at risk of cysticercosis, 2009. [http://gamap server.who.int/mapLibrary/Files/Maps/Global_cysticercosis_2009.png].

33. Devleesschauwer B, Aryal A, Joshi DD, Rijal S, Sherchand JB, Praet N, et al. Epidemiology of Taenia solium in Nepal: is it influenced by the social characteristics of the population and the presence of Taenia asiatica? Trop Med Int Health. 2012;17(8):1019-22.

34. WHO. Schistosomiasis: number of people treated worldwide in 2013. Wkly Epidemiol Rec. 2015;90:25-32.

35. Naus CW, Booth M, Jones FM, Kemijumbi J, Vennervald BJ, Kariuki CH, et al. The relationship between age, sex, egg-count and specific antibody responses against Schistosoma mansoni antigens in a Ugandan fishing community. Trop Med Int Health. 2003;8(6):561-8.

36. Mwape KE, Phiri IK, Praet N, Muma JB, Zulu G, Van den Bossche P, et al. Taenia solium infections in a Rural Area of Eastern Zambia - A community based study. Plos Negl Trop Dis. 2012;6(3):e1594.

37. Kyvsgaard NC, Johansen MV, Carabin H. Simulating transmission and control of Taenia solium infections using a Reed-Frost stochastic model. Int J Parasitol. 2007;37(5):547-58.

38. Kanobana K, Praet N, Kabwe C, Dorny P, Lukanu P, Madinga J, et al. High prevalence of Taenia solium cysticerosis in a village community of Bas-Congo, Democratic Republic of Congo. Int J Parasitol. 2011:41(10):1015-8.

39. Mwanjali G, Kihamia C, Kakoko DVC, Lekule F, Ngowi H, Johansen MV, et al. Prevalence and risk factors associated with human Taenia solium infections in Mbozi district, Mbeya Region, Tanzania. Plos Negl Trop Dis. 2013;7(3):e2102.

40. Weka RP, Ikeh El, Kamani J. Seroprevalence of antibodies (lgG) to Taenia solium among pig rearers and associated risk factors in Jos metropolis, Nigeria. J Infect Dev Ctries. 2013;7(2):67-72.

41. Prado-Jean A, Kanobana K, Druet-Cabanac M, Nsengyiumva G, Dorny P, Preux PM, et al. Combined use of an antigen and antibody detection enzyme-linked immunosorbent assay for cysticercosis as tools in an epidemiological study of epilepsy in Burundi. Trop Med Int Health. 2007;12(7):895-901.

42. Praet N, Speybroeck N, Rodriguez-Hidalgo R, Benitez-Ortiz W, Berkvens D, Brandt J, et al. Age-related infection and transmission patterns of human cysticercosis. Int J Parasitol. 2010;40(1):85-90.

43. Thomson AJ, De Villiers JC, Moosa A, Van Dellen J. Cerebral cysticercosis in children in South Africa. Ann Trop Paediatr. 1984:4(2):67-77.

44. Schantz PM, Moore AC, Muñoz JL, Hartman BJ, Schaefer JA, Aron AM, et al. Neurocysticercosis in an orthodox Jewish community in New York City. N Engl J Med. 1992;327(10):692-5

45. Al Shahrani D, Frayha HH, Dabbagh O, Al Shail E. First case of neurocysticercosis in Saudi Arabia. J Trop Pediatr. 2003;49(1):58-60.

46. Khan FY, Imam YZ, Kamel H, Shafaee M. Neurocysticercosis in Qatari patients: case reports. Travel Med Infect Dis. 2011;9(6):298-302.

47. Hira PR, Francis I, Abdella NA, Gupta R, Al-Ali FM, Grover S, et al. Cysticercosis: imported and autochthonous infections in Kuwait. Trans R Soc Trop Med Hyg. 2004;98(4):233-9.

48. Begg CB. Biases in the assessment of diagnostic tests. Stat Med. 1987;6(4):411-23.

49. Greiner $M$, Gardner I. Epidemiologic issues in the validation of veterinary diagnostic tests. Prev Vet Med. 2000;45(1):3-22.

50. Devleesschauwer B, Ale A, Torgerson P, Praet N, de Noordhout CM, Pandey BD, et al. The burden of parasitic zoonoses in Nepal: a systematic review. Plos Negl Trop Dis. 2014;8(1):e2634.

51. Pondja A, Neves L, Mlangwa J, Afonso S, Fafetine J, Willingham AL, et al. Prevalence and risk factors of porcine cysticercosis in Angonia District, Mozambique. Plos Negl Trop Dis. 2010;4(2):e594.

52. Sikasunge CS, Phiri IK, Phiri AM, Dorny P, Siziya S, Willingham III AL. Risk factors associated with porcine cysticercosis in selected districts of Eastern and Southern provinces of Zambia. Vet Parasitol. 2007;143(1):59-66.

53. Garcia HH, Gonzalez AE, Evans CAW, Gilman RH, Cysticercosis Working Grp P. Taenia solium cysticercosis. Lancet. 2003;362(9383):547-56.

54. Krecek RC, Michael LM, Schantz PM, Ntanjana L, Smith MF, Dorny P, et al. Corrigendum to "Prevalence of Taenia solium cysticercosis in swine from a community-based study in 21 villages of the Eastern Cape Province, South Africa" [Vet. Parasitol. 154(2008) 38-47]. Vet Parasitol. 2011;183(1-2):198-200. 
55. Krecek RC, Michael LM, Schantz PM, Ntanjana L, Smith MF, Dorny P, et al. Prevalence of Taenia solium cysticercosis in swine from a community-based study in 21 villages of the Eastern Cape Province, South Africa. Vet Parasitol. 2008;154(1-2):38-47.

56. Praet N, Verweij JJ, Mwape KE, Phiri IK, Muma JB, Zulu G, et al. Bayesian modelling to estimate the test characteristics of coprology, coproantigen ELISA and a novel real-time PCR for the diagnosis of taeniasis. Trop Med Int Health. 2013;18(5):608-14.

57. Tomlinson M, Adams V, Chopra M, Jooste P, Strydom E, Dhansay A. Survey of iodine deficiency and intestinal parasitic infections in school-going children: Bie Province, Angola. Public Health Nutr. 2010;13(9):1314.

58. Goussanou JSE, Kpodekon TM, Saegerman C, Azagoun E, Youssao AKI, Farougou S, et al. Spatial distribution and risks factors of porcine cysticercosis in southern Benin based meat inspection records. Int Res J Microbiol. 2013:4:188-96.

59. Adjidé C, Bouteille B, Josse R, Adjidé-Szmidt V, Avodé D, Dumas M. Séroprévalence de la cysticercose dans la commune lacustre de Vekky, Département de l'Atlantique (Bénin). Bull Soc Pathol Exo. 1996;89(1):24-9.

60. Avode DG, Bouteille B, Houngbe F, Adjien C, Adjide C, Houinato D, et al. Epilepsy, cysticercosis and neurocysticercosis in Benin. Eur Neurol. 1998;39(1):60-1.

61. Houinato D, Ramanankandrasana B, Adjide C, Melaku Z, Josse R, Avode G, et al. Seroprevalence of cysticercosis in Benin. Trans R Soc Trop Med Hyg. 1998;92(6):621-4

62. Ganaba R, Praet N, Carabin H, Millogo A, Tarnagda Z, Dorny P, et al. Factors associated with the prevalence of circulating antigens to porcine cysticercosis in Three Villages of Burkina Faso. Plos Negl Trop Dis. 2011;5(1):e927.

63. Barro-Traoré F, Ouédraogo M, Sanou-Lamien A, Lompo-Goumbri O, Bassolé A, Sawadogo S, et al. Cysticercose sous-cutanée généralisée: à propos de six cas au Burkina Faso. Bull Soc Pathol Exot. 2008;101(1):17-9.

64. Carabin H, Millogo A, Praet N, Hounton S, Tarnagda Z, Ganaba R, et al. Seroprevalence to the antigens of Taenia solium Cysticercosis among residents of Three Villages in Burkina Faso: A Cross-Sectional Study. Plos Negl Trop Dis. 2009;3(11):e555.

65. Fortunato S, Castagna B, Monteleone MR, Pierro R, Cringoli G, Bruschi F. Parasite prevalence in a village in Burkina Faso: the contribution of new techniques. J Infect Dev Ctries. 2014;8(5):670-5.

66. Millogo A, Nitiéma P, Carabin H, Boncoeur-Martel MP, Rajshekhar V, Tarnagda Z, et al. Prevalence of neurocysticercosis among people with epilepsy in rural areas of Burkina Faso. Epilepsia. 2012;53(12):2194-202.

67. Napon C, Ouédraogo D, Diallo O, Kapto O, Kabore J. Syndrome de Wallenberg et neurocysticercose: à propos d'un cas à Ouagadougou, Burkina Faso. Bull Soc Pathol Exot. 2009;102(1):5-6.

68. Nitiéma P, Carabin H, Hounton S, Praet N, Cowan L, Ganaba R, et al. Prevalence case-control study of epilepsy in three Burkina Faso villages. Acta Neurol Scand. 2012;126(4):270-8.

69. Sakandé B, Traoré S, Kaboré J, Ouattara T, Soudré R. Parasitoses humaines au Burkina Faso, Approche histopathologique. Bull Soc Pathol Exot. 1998;91:217-20.

70. Newell E, Vyungimana F, Geerts S, VanKerckhoven I, Tsang VCW, Engels D. Prevalence of cysticercosis in epileptics and members of their families in Burundi. Trans R Soc Trop Med Hyg. 1997;91(4):389-91.

71. Diagana M, Nsengiyumva G, Tuillas M, Druet-Cabanac M, Bouteille B, Preux PM, et al. Électroencéphalogrammes réalisés chez 250 patients épileptiques dans une zone d'endémie cysticerquienne au Burund. Neurophysiol Clin. 2005:35(1):1-10.

72. Nsengiyumva G, Druet-Cabanac M, Ramanankandrasana B, Bouteille B, Nsizabira L, Preux PM. Cysticercosis as a major risk factor for epilepsy in Burundi, East Africa. Epilepsia. 2003:44(7):950-5.

73. Nzisabira L, Nsengiyumva G, Bouteille B, Ndayiragije A, Niyongabo T, Bigirimana $V$, et al. Cysticercosis in the province of Kayanza (Burundi). Bull Soc Pathol Exo. 1991;85(5):374-7.

74. Assana E, Amadou F, Thys E, Lightowlers MW, Zoli AP, Dorny P, et al. Pig-farming systems and porcine cysticercosis in the north of Cameroon. J Helminthol. 2010;84(4):441-6.

75. Ngwing NAN, Pone JW, Mbida M, Pagnah AZ, Njakoi H, Bilong CFB. A preliminary analysis of some epidemiological factors involved in porcine cysticercosis in Bafut and Santa subdivisions, North West Region of Cameroon. Asian Pac J Trop Med. 2012;5(10):814-7.

76. Pouedet MSR, Zoli AP, Nguekam, Vondou L, Assana E, Speybroeck N, et al. Epidemiological survey of swine cysticercosis in two rural communities of West-Cameroon. Vet Parasitol. 2002;106(1):45-54.
77. Shey-Njila O, Zoli P, Awah-Ndukum J, Assana E, Byambas P, Dorny P, et al. Porcine cysticercosis in village pigs of North-West Cameroon. J Helminthol. 2003;77(4):351.

78. Assana E, Zoli P, Sadou H, Vondou L, Pouedet M, Dorny P, et al. Prevalence of porcine cysticercosis in Mayo-Danay (North Cameroon) and Mayo-Kebbi (Southwest Chad). Rev Elev Med Vet Pays Trop. 2001;54(2):123-7.

79. Marty P, Mary C, Pagliardini G, Quilici M, Le Fichoux Y. Deux cas de Cysticercose observé au Cameroun. Med Trop (Mars). 1986;46(2):181-3.

80. Vondou L, Zoli A, Pouedet S, Assana E, Kamga Tokam A, Dorny P, et al. La taeniose/cysticercose à Taenia solium dans la Menoua (Ouest-cameroun). Parasite. 2002;9(3):271-4.

81. Dongmo L, Druet-Cabanac M, Moyou S, Zebaze D, Njamnshi A, Sini V, et al. Cysticercose et épilepsie: étude cas-témoins dans la Vallée du Mbam, Cameroun. Bull Soc Pathol Exot. 2004;97(2):105-8.

82. Elliott I, Jerome A, Angwafor SA, Smith ML, Takougang I, Noh J, et al. Epilepsy and cysticercosis in North-West Cameroon: A serological study. Seizure. 2013;22(4):283-6.

83. Gascon J, Corachan M, Ramirez J. 5 cases of cysticercosis in Rwanda. Med Trop (Mars). 1989;49(1):77.

84. Nguekam, Zoli AP, Ongolo-Zogo P, Dorny P, Brandt J, Geerts S. Follow-up of neurocysticercosis patients after treatment using an antigen detection ELISA. Parasite. 2003:10(1):65-8.

85. Nguekam JP, Zoli AP, Zogo PO, Kamga ACT, Speybroeck N, Dorny P, et al. A seroepidemiological study of human cysticercosis in West Cameroon. Trop Med Int Health. 2003;8(2):144-9.

86. Nkouawa A, Sako Y, Itoh S, Kouojip-Mabou A, Nganou CN, Saijo Y, et al. Serological studies of neurologic helminthic infections in rural areas of southwest Cameroon: toxocariasis, cysticercosis and paragonimiasis. Plos Negl Trop Dis. 2010;4(7):e732.

87. Zoli AP, Nguekam A, Shey-Njila O, Nforninwe DN, Speybroeek N, Ito A, et al. Neurocysticercosis and epilepsy in Cameroon. Trans R Soc Trop Med Hyg. 2003;97(6):683-6.

88. Druet-Cabanac M, Preux PM, Bouteille B, Bernet-Bernady P, Dunand J, Hopkins A, et al. Onchocerciasis and epilepsy: A matched case-control study in the Central African Republic. Am J Epidemiol. 1999;149(6):565-70.

89. Chartier C, Mutesi U, Ndakala N. Les helminthes du porc domestique en Ituri, haut Zaïre. In: Annales de la société belge de médecine tropicale. 1990. p. 213-25.

90. Praet N, Kanobana K, Kabwe C, Maketa V, Lukanu P, Lutumba P, et al. Taenia solium Cysticercosis in the Democratic Republic of Congo: How does pork trade affect the transmission of the parasite? Plos Negl Trop Dis. 2010;4:9.

91. Haridy FM, Ibrahim BB, Morsy TA, Ramadan NII. Human taenaisis and cysticercosis in slaughtered cattle, buffaloes and pigs in Egypt. J Egypt Soc Parasitol. 1999:29(2):375-94

92. Okome-Nkoumou M, Ondounda M, Dzeing-Ella A, Mounguengui D, Nziengui Madjinou M, Magne C, et al. Epileptiform seizures revealing neurocysticercosis: report of two clinical cases in Libreville, Gabon. Asian Pac J Trop Med. 2010;3(8):671-2.

93. Secka A, Marcotty T, De Deken R, Van Marck E, Geerts S. Porcine cysticercosis and risk factors in The Gambia and Senegal. J Parasitol Res. 2010;2010:823892.

94. Permin A, Yelifari L, Bloch P, Steenhard N, Hansen NP, Nansen P. Parasites in cross-bred pigs in the Upper East Region of Ghana. Vet Parasitol. 1999;87(1):63-71

95. Ngugi AK, Bottomley C, Kleinschmidt I, Wagner RG, Kakooza-Mwesige A, Ae-Ngibise K, et al. Prevalence of active convulsive epilepsy in sub-Saharan Africa and associated risk factors: cross-sectional and case-control studies. Lancet Neurol. 2013;12(3):253-63.

96. Pampiglione S, Ricciardi ML, Visconti S, Branca A, Olivieri E, Zamberletti A. Ricerche sui parassiti intestinali dell'uomo in Africa subsahariana. 1. Boe Orientale e Isola de Canhabaque (Guinea-Bissau). Parassitologia. 1987;29(1):1-13.

97. Carstensen H, Hansen HL, Kristiansen HO, Gomme G. The epidemiology of cryptosporidiosis and other intestinal parasitoses in children in southern Guinea-Bissau. Trans R Soc Trop Med Hyg. 1987;81(5):860-4.

98. Githigia S, Murekefu A, Otieno R. Prevalence of porcine cysticercosis and risk factors for Taenia solium taeniosis in Funyula Division of Busia District, Kenya. Kenya Veterinarian. 2007;29(1):37-9.

99. Kagira JM, Maingi N, Kanyari PWN, Githigia SM, Ng'ang'a JC, Gachohi JM. Seroprevalence of Cysticercus cellulosae and associated risk factors in free-range pigs in Kenya. J Helminthol. 2010;84(4):398-403.

100. Mutua FK, Randolph TF, Arimi SM, Kitala PM, Githigia SM, Willingham AL, et al. Palpable lingual cysts, a possible indicator of porcine cysticercosis, in Teso District, Western Kenya. J Swine Health Prod. 2007;15(4):206. 
101. Waruingi M, Ramanankandrasana B, Druet-Cabanac M, Nsengiyumva G, Bouteille B, Preux P. Kenya: a new human cysticercosis focus. Afr J Neurol Sci. 2002;21:46.

102. Michelet L, Carod J-F, Rakontondrazaka M, Ma L, Gay F, Dauga C. The pig tapeworm Taenia solium, the cause of cysticercosis: Biogeographic (temporal and spacial) origins in Madagascar. Mol Phylogenet Evol. 2010;55(2):744-50.

103. Ramahefarisoa RM, Rakotondrazaka M, Jambou R, Carod JF. Comparison of ELISA and PCR assays for the diagnosis of porcine cysticercosis. Vet Parasitol. 2010;173(3-4):336-9.

104. Yanagida T, Carod JF, Sako Y, Nakao M, Hoberg EP, Ito A. Genetics of the pig tapeworm in madagascar reveal a history of human dispersal and colonization. PLoS One. 2014;9(10), e109002.

105. Buchy P. Intestinal parasitoses in the Mahajanga region, west coast of Madagascar. Bull Soc Pathol Exo. 2003;96(1):41-5.

106. Andriantsimahavandy A, Lesbordes JL, Rasoaharimalala B, Peghini M Rabarijaona L, Roux J, et al. Neurocysticercosis: A major aetiological factor of late-onset epilepsy in Madagascar. Trop Med Int Health. 1997;2(8):741-6.

107. Barba G, Doireau V, Lippa A, Tauzin C, Mensire A, Choulot JJ, et al. Cas radiologique du mois. Arch Pediatr. 1999;6(3):315-6.

108. Bernardin P, Auzemery A, Rabenantoandro C. La cysticercose oculaire (C.O.) a Madagascar (a propos de 6 cas). Rev Int Trach Pathol Ocul Trop Subtrop Sante Publique. 1994;71:103-13.

109. Grill J, Rakotomalala W, Andriantsimahavandy A, Boisier P, Guyon P, Roux J, et al. High prevalence of serological markers of cysticercosis among epileptic Malagasy children. Ann Trop Paediatr. 1996;16(3):185-91.

110. Michel P, Callies P, Raharison H, Guyon P, Holvoet L, Genin C. Epidemiology of cysticercosis in Madagascar. Bull Soc Pathol Exo. 1993;86(1):62.

111. Migliani R, Rasolomaharo M, Rajaonarison P, Ravaoalimalala V, Rabarijaona L, Andriantsimahavandy A. La cysticercose dans le port de Mahajanga: plus fréquente qu'on ne l'imagine! Arch Inst Pasteur Madagascar. 2000;66(1-2):39-42.

112. Kumwenda JJ, Mateyu G, Kampondeni S, van Dam AP, van Lieshout L, Zijlstra EE. Differential diagnosis of stroke in a setting of high HIV prevalence in Blantyre, Malawi. Stroke. 2005;36(5):960-4.

113. Maïga Y, Diallo $M$, Bouteille $B$, Konate A, Diarra M, Maïga $M$, et al. Àpropos d'un cas autochtone de neurocysticercose au Mali (premier cas de la littérature?). Bull Soc Pathol Exo. 2009:102(4):211-4.

114. Matos C, Sitoe C, Afonso S, Banze J, Baptista J, Dias G, et al. A pilot study of common health problems in smallholder pigs in Angónia and Boane districts, Mozambique. J S Afr Vet Assoc. 2011;82(3):166-9.

115. Pondja A, Neves L, Mlangwa J, Afonso S, Fafetine J, Willingham AL, et al. Use of oxfendazole to control porcine cysticercosis in a high-endemic area of mozambique. Plos Negl Trop Dis. 2012;6(5):e1651.

116. Noormahomed EV, Pividal JG, Azzouz S, Mascaro C, Delgado-Rodriguez M, Osuna A. Seroprevalence of anti-cysticercus antibodies among the children living in the urban environs of Maputo, Mozambique. Ann Trop Med Parasitol. 2003;97(1):31-5.

117. Noormahomed EV, Nhacupe N, Mascaró-Lazcano C, Mauaie MN, Buene T, Funzamo CA, et al. A cross-sectional serological study of cysticercosis, schistosomiasis, toxocariasis and echinococcosis in HIV-1 infected people in Beira, Mozambique. Plos Negl Trop Dis. 2014;8(9), e3121.

118. Vilhena M, Santos M, Torgal J. Seroprevalence of human cysticercosis in Maputo, Mozambique. Am J Trop Med Hyg. 1999;61(1):59-62.

119. Biu AA, ljudai J. Prevalence and morphometric studies on porcine cysticercosis in Adamawa State, Nigeria. Sokoto J Vet Sci. 2012;10(1):28-31.

120. Gweba M, Faleke OO, Junaidu AU, Fabiyi JP, Fajinmi AO. Some risk factors for Taenia solium cysticercosis in semi-intensively raised pigs in Zuru, Nigeria. Vet Ital. 2010;46(1):57-67.

121. Karshima N, Bobbo A, Udokainyang A, Salihu A. Taenia Solium Cysticercosis in pigs slaughtered in IBI local government area of Taraba State, Nigeria. J Anim Sci Adv. 2013:3(3):109-13.

122. Oladele SB, Ibrahim NDG, Fatihu MY, Mohammed B, Sambo SJ, Aluko RK. Twenty six years retrospective studies of the prevalence of gastrointestinal helminths isolated from necropsied animals in Zaria, Nigeria. Bull Epizoot Dis Afr. 2006;54(4):234-40.

123. Onah DN, Chiejina SN. Taenia soluim cysticercosis and human taeniasis in the Nsukka area of Enugu State, Nigeria. Ann Trop Med Parasitol. 1995;89(4):399-407.

124. Agbolade OM, Agu NC, Adesanya OO, Odejayi AO, Adigun AA, Adesanlu EB, et al. Intestinal helminthiases and schistosomiasis among school children in an urban center and some rural communities in southwest Nigeria. Korean J Parasitol. 2007;45(3):233-8.
125. Akogun OB. Some social aspects of helminthiasis among the people of Gumau District, Bauchi State, Nigeria. J Trop Med Hyg. 1989;92(3):193-6.

126. Ekpo UF, Odoemene SN, Mafiana CF, Sam-Wobo SO. Helminthiasis and hygiene conditions of schools in Ikenne, Ogun State, Nigeria. PLoS Negl Trop Dis. 2008;2(1):e146.

127. Ojurongbe O, Raji OA, Akindele AA, Kareem Ml, Adefioye OA, Adeyeba AO Cryptosporidium and other enteric parasitic infections in HIV-seropositive individuals with and without diarrhoea in Osogbo, Nigeria. Br J Biomed Sci. 2011;68(2):75-8.

128. Kanu I, Anyanwu EC, Nwachukwu NC, Ehiri JE, Merrick J. Clinical microbiological aspects of epileptic seizures in the tropical countries with specific focus on Nigeria. Sci World J. 2005;5:401-9.

129. Omonisi AE, Odujoko OO, Aluko JA, Akinyemi HA, Alatishe Ol, Omoniyi-Esan GO. Human cysticercosis of the breast mimicking breast cancer: a report of a case from Ile-Ife, Nigeria. Niger J Med. 2014;23(4):351-4.

130. Rottbeck R, Nshimiyimana JF, Tugirimana P, Dull UE, Sattler J, Hategekimana $J C$, et al. High prevalence of cysticercosis in people with epilepsy in southern rwanda. Plos Negl Trop Dis. 2013;7(11):e2558.

131. Ndiaye D, Ndiaye M, Gueye PA, Badiane A, Fall ID, Ndiaye YD, et al. Intestinal helminthiasis diagnosed in Dakar, Senegal. Med Sante Trop. 2013;23(1):35-8.

132. Secka A, Grimm F, Marcotty T, Geysen D, Niang AM, Ngale V, et al. Old focus of cysticercosis in a senegalese village revisited after half a century. Acta Trop. 2011;119(2-3):199-202.

133. Pammenter M, Rossouw E, Dingle C. Serological detection of cysticercosis in two rural areas of South Africa. Trans R Soc Trop Med Hyg. 1987;81(2):242-4.

134. Tronnberg L, Hawksworth D, Hansen A, Archer C, Stenstrom TA. Householdbased prevalence of helminths and parasitic protozoa in rural KwaZuluNatal, South Africa, assessed from faecal vault sampling. Trans R Soc Trop Med Hyg. 2010;104(10):646-52.

135. Foyaca-Sibat H, Cowan LD, Carabin H, Targonska I, Anwary MA, SerranoOcana G, et al. Accuracy of serological testing for the diagnosis of prevalent neurocysticercosis in outpatients with epilepsy, Eastern Cape Province, South Africa. PLoS Negl Trop Dis. 2009;3(12), e562.

136. Mafojane NA. The neurocysticercosis project in Atteridgeville-Mamelodi townships. S Afr Med J. 1994;84:208-11.

137. Naidoo D, Pammenter M, Moosa A, Van Dellen J, Cosnett J. Seventy black epileptics. Cysticercosis, computed tomography and electro-encephalography. S Afr Med J. 1987;72(12):837-8.

138. Sacks LV, Berkowitz I. Cysticercosis in an urban black South African community: prevalence and risk factors. Trop Gastroenterol. 1990;11(1):30-3.

139. Shasha W, Pammenter M. Sero-epidemiological studies of cysticercosis in school children from two rural areas of Transkei, South Africa. Ann Trop Med Parasitol. 1991:85(3):349-55.

140. van As AD, Joubert J. Neurocysticercosis in 578 black epileptic patients. S Afr Med J. 1991;80(7):327-8.

141. Boa ME, Mahundi EA, Kassuku AA, Willingham AL, Kyvsgaard NC. Epidemiological survey of swine cysticercosis using ante-mortem and post-mortem examination tests in the southern highlands of Tanzania. Vet Parasitol. 2006;139(1-3):249-55.

142. Boa ME, Bogh HO, Kassuku AA, Nansen P. The prevalence of Taenia solium metacestodes in pigs in northern Tanzania. J Helminthol. 1995;69(2):113-7.

143. Boa ME, Kassuku AA, Willingham AL, Keyyu JD, Phiri IK, Nansen P. Distribution and density of cysticerci of Taenia solium by muscle groups and organs in naturally infected local finished pigs in Tanzania. Vet Parasitol. 2002;106(2):155-64.

144. Braae UC, Magnussen P, Lekule F, Harrison W, Johansen MV. Temporal fluctuations in the sero-prevalence of Taenia solium cysticercosis in pigs in Mbeya Region, Tanzania. Parasit Vectors. 2014;7(1):574.

145. Mkupasi E, Ngowi H, Sikasunge C, Leifsson P, Johansen M. Distribution and histopathological changes induced by cysts of Taenia solium in the brain of pigs from Tanzania. J Helminthol. 2014;1-6.

146. Mkupasi EM, Ngowi HA, Sikasunge CS, Leifsson PS, Johansen MV. Efficacy of ivermectin and oxfendazole against Taenia solium cysticercosis and other parasitoses in naturally infected pigs. Acta Trop. 2013;128(1):48-53.

147. Ngowi HA, Carabin H, Kassuku AA, Mlozi MRS, Mlangwa JED, Willingham AL. A health-education intervention trial to reduce porcine cysticercosis in Mbulu District, Tanzania. Prev Vet Med. 2008;85(1-2):52-67.

148. Ngowi HA, Kassuku AA, Maeda GEM, Boa ME, Willingham AL. A slaughte slab survey for extra-intestinal porcine helminth infections in northern Tanzania. Trop Anim Health Pro. 2004;36(4):335-40.

149. Ngowi HA, Kassuku AA, Maeda GEM, Boa ME, Carabin H, Willingham AL. Risk factors for the prevalence of porcine cysticercosis in Mbulu District, Tanzania. Vet Parasitol. 2004;120(4):275-83. 
150. Yohana C, Mwita CJ, Nkwengulila G. The prevalence of porcine cysticercosis and risk factors for taeniasis in Iringa rural district. Int J Anim Vet Adv. 2013;5(6):251-5.

151. Eom KS, Chai J-Y, Yong T-S, Min D-Y, Rim H-J, Kihamia C, et al. Morphologic and Genetic Identification of Taenia Tapeworms in Tanzania and DNA Genotyping of Taenia solium. Korean J Parasitol. 2011;49(4):399-403.

152. Blocher J, Schmutzhard E, Wilkins PP, Gupton PN, Schaffert M, Auer H, et al. A cross-sectional study of people with Epilepsy and Neurocysticercosis in Tanzania: Clinical characteristics and diagnostic approaches. Plos Negl Trop Dis. 2011;5(6):e1185.

153. Mwang'onde BJ, Nkwengulila G, Chacha M. The serological survey for human cysticercosis prevalence in Mbulu District, Tanzania. Adv Infect Dis. 2012;2:62.

154. Mwang'onde BJ, Nkwengulila G, Chacha M. The risk factors for human cysticercosis in Mbulu District, Tanzania. Onderstepoort J Vet Res. 2014;81(2):5.

155. Winkler AS, Blocher J, Auer H, Gotwald T, Matuja W, Schmutzhard E. Anticysticercal and antitoxocaral antibodies in people with epilepsy in rural Tanzania. Trans R Soc Trop Med Hyg. 2008;102(10):1032-8.

156. Winkler AS, Blocher J, Auer H, Gotwald T, Matuja W, Schmutzhard E. Epilepsy and neurocysticercosis in rural Tanzania —an imaging study. Epilepsia. 2009;50(5):987-93.

157. Dumas M, Grunitzky K, Belo M, Dabis F, Deniau M, Bouteille B, et al. Cysticercose et neurocysticercose: enquête épidémiologique dans le nord du Togo. Bull Soc Pathol Exo. 1990;83(2):263-74.

158. Balogou A, Grunitzky K, Beketi K, Bouteille B, Dumas M. Cysticercosis and epilepsy in the city of Tone, north of Togo. Rev Neurol (Paris). 2000;156(3):270-3.

159. Belo M, Grunitzky EK, Balogou A, Kowu L. Cysticercose cérébrale et céphalées chez une jeune femme togolaise. Rev Neurol (Paris). 2001;157(4):433.

160. Dumas M, Grunitzky E, Deniau M, Dabis F, Bouteille B, Belo M, et al. Epidemiological study of nuerocysticercosis in northern Togo West Africa. Acta Leiden. 1989;57(2):191-6.

161. Grunitzky E, Balogou AK, M'Bella M, Mofou B, Sadzo A, Bouteille B, et al. La cysticercose chez des malades neurologiques en milieu hospitalier à Lomé Togo. Ann Med Interne (Paris). 1995;146(6):419-22.

162. Anyanzo T. Prevalence of Cysticercosis cellulosae in three sub-counties of Moyo County, Moyo District, Uganda. In: Bachelor of Veterinary Medicine Special Project Report, Faculty of Medicine, Makerere University, Kampala, Uganda. 1999.

163. Kisakye J, Masaba S. Cysticercus cellulosae in pigs slaughtered in and around Kampala City. Ug J Agric Sci. 2002;7:23-4.

164. Nsadha Z, Thomas LF, Fèvre EM, Nasinyama G, Ojok L, Waiswa C. Prevalence of porcine cysticercosis in the Lake Kyoga Basin, Uganda. BMC Vet Res. 2014;10(1):239.

165. Nsadha Z, Saimo M, Waiswa C, Ojok L, Willingham A, Mutagwanya R, et al, Risk factors and lingual prevalence of porcine cysticercosis in the Lake Kyoga Basin in Uganda. Afri J Anim Biomed Sci. 2010;5(3):43-50.

166. Nsadha Z, Saimo M, Waiswa C, Nabwire I, Nkwole A, Sikasunge C, et al. Trans-boundary porcine cysticercosis a possibility on Uganda's boarders. Afri J Anim Biomed Sci. 2011;6(1):67-71.

167. Waiswa C, Fevre EM, Nsadha Z, Sikasunge CS, Willingham AL. Porcine cysticercosis in southeast Uganda: seroprevalence in kamuli and kaliro districts. J Parasitol Res. 2009;2009.

168. Kabatereine NB, Kemijumbi J, Kazibwe F, Onapa AW. Human intestinal parasites in primary school children in Kampala, Uganda. East Afr Med J. 1997;74(5):311-4.

169. Katabarwa M, Lakwo T, Habumogisha P, Richards F, Eberhard M. Could neurocysticercosis be the cause of "onchocerciasis-associated" epileptic seizures? Am J Trop Med Hyg. 2008;78(3):400-1.

170. Phiri I, Dorny P, Gabriël S, Willingham AL, Sikasunge C, Siziya S, et al. Assessment of routine inspection methods for porcine cysticercosis in Zambian village pigs. J Helminthol. 2006;80(1):69-72.

171. Phiri IK, Dorny P, Gabriel S, Willingham AL, Speybroeck N, Vercruysse J. The prevalence of porcine cysticercosis in Eastern and Southern provinces of Zambia. Vet Parasitol. 2002;108(1):31-9.

172. Sikasunge CS, Phiri IK, Phiri AM, Siziya S, Dorny P, Willingham III AL. Prevalence of Taenia solium porcine cysticercosis in the Eastern, Southern and Western provinces of Zambia. Vet J. 2008;176(2):240-4.
173. Mwape KE, Phiri IK, Praet N, Speybroeck N, Muma JB, Dorny P, et al. The incidence of human cysticercosis in a rural community of Eastern Zambia. Plos Negl Trop Dis. 2013;7(3):e2142.

174. Mwape KE, Phiri IK, Praet N, Dorny P, Muma JB, Zulu G, et al. Study and ranking of determinants of Taenia solium infections by classification tree models. Am J Trop Med Hyg. 2015;92(1):56-63.

175. Siwila J, Phiri IG, Enemark HL, Nchito M, Olsen A. Intestinal helminths and protozoa in children in pre-schools in Kafue district, Zambia. Trans R Soc Trop Med Hyg. 2010;104(2):122-8.

176. Cortnum S, Knudsen KB, Sorensen P. Kirurgisk behandling af neurocysticerkose hos et 12-årigt barn. Ugeskr Laeger. 2011;173(36):2203-4

177. Mwape KE, Praet N, Benitez-Ortiz W, Muma JB, Zulu G, Celi-Erazo M, et al. Field evaluation of urine antigen detection for diagnosis of Taenia solium cysticercosis. Trans R Soc Trop Med Hyg. 2011;105(10):574-8.

178. Matenga E, Mukaratirwa S, Willingham A. Prevalence of porcine cysticercosis and hydatidosis in slaughtered animals in southwestern Zimbabwe: a retrospective study. In: Proceedings of the 11th Annual Meeting of ENRECA Livestock Helminths Research Project in Eastern and Southern Africa, 6-9 June 2002. 2002.

179. Baily GG, Levy LF. Racemose cysticercosis treated with praziquantel. Trans R Soc Trop Med Hyg. 1989;83(1):95-6.

180. Mason P, Houston S, Gwanzura L. Neurocysticercosis: experience with diagnosis by ELISA serology and computerized tomography in Zimbabwe. Cent Afr J Med. 1992;38(4):149-54.

\section{Submit your next manuscript to BioMed Central and take full advantage of:}

- Convenient online submission

- Thorough peer review

- No space constraints or color figure charges

- Immediate publication on acceptance

- Inclusion in PubMed, CAS, Scopus and Google Scholar

- Research which is freely available for redistribution 